\title{
OPEN Genomic analysis of Bacillus cereus NWUAB01 and its heavy metal removal from polluted soil
}

\begin{abstract}
Ayansina Segun Ayangbenro \& Olubukola Oluranti Babalola ${ }^{凶}$
Microorganisms that display unique biotechnological characteristics are usually selected for industrial applications. Bacillus cereus NWUAB01 was isolated from a mining soil and its heavy metal resistance was determined on Luria-Bertani agar. The biosurfactant production was determined by screening methods such as drop collapse, emulsification and surface tension measurement. The biosurfactant produced was evaluated for metal removal ( $100 \mathrm{mg} / \mathrm{L}$ of each metal) from contaminated soil. The genome of the organism was sequenced using Illumina Miseq platform. Strain NWUAB01 tolerated $200 \mathrm{mg} / \mathrm{L}$ of $\mathrm{Cd}$ and $\mathrm{Cr}$, and was also tolerant to $1000 \mathrm{mg} / \mathrm{L}$ of $\mathrm{Pb}$. The biosurfactant was characterised as a lipopeptide with a metal-complexing property. The biosurfactant had a surface tension of $39.5 \mathrm{mN} / \mathrm{m}$ with metal removal efficiency of $69 \%, 54 \%$ and $43 \%$ for $\mathrm{Pb}, \mathrm{Cd}$ and $\mathrm{Cr}$ respectively. The genome revealed genes responsible for metal transport/resistance and biosynthetic gene clusters involved in the synthesis of various secondary metabolites. Putative genes for transport/resistance to cadmium, chromium, copper, arsenic, lead and zinc were present in the genome. Genes responsible for biopolymer synthesis were also present in the genome. This study highlights biosurfactant production and heavy metal removal of strain NWUAB01 that can be harnessed for biotechnological applications.
\end{abstract}

Industrialisation and mining activities have continued to put an increasing burden on the environment as a result of metal pollution ${ }^{1}$. The unrestrained release of metals into the environment from these activities poses a threat to the ecosystem and health of living organisms. Mining industries, fertilizer and pesticide production release cadmium into the environment ${ }^{2}$. Mining, electroplating, paints and pigments, batteries, tanning and textile industries release chromium and lead into the environment ${ }^{2-4}$. Heavy metals have been known to cause various diseases and ailments in humans, for example, cadmium causes bone disease, headache, hypertension, kidney diseases, lung and prostate cancer ${ }^{2,3,5}$. Chromium causes chronic bronchitis, skin irritation, liver diseases, renal failure and lung cancer ${ }^{4,6}$ while lead causes chronic nephropathy insomnia, learning disorder, renal damage, reduced fertility and is a risk factor for Alzheimer's disease $e^{2,5,7}$.

Conventional methods of heavy metal removal involve treatment with chelating agents, organic and inorganic acids, reverse osmosis, surfactants and water. However, these techniques are often expensive and ineffective for low metal concentration removal ${ }^{1,5}$. Other challenges often encountered with the use of these conventional techniques include non-specificity of these methods, space requirements, impractical nature of some techniques and high energy demand ${ }^{1,8}$. Thus, there is the need for bioremediation using microorganisms with potential for remediation of polluted environments and production of eco-friendly secondary metabolites 9 .

Bioremediation of heavy metals offers an alternative and effective means of decontaminating metal-polluted environments. Heavy metal remediation of contaminated environment mediated by microorganisms is efficient and cost effective ${ }^{8}$. Microorganisms have developed various mechanisms for detoxifying heavy metals. These mechanisms include biosorption, biotransformation, bioaccumulation, and biomineralisation ${ }^{10}$. These organisms also secrete a range of metal-sequestering polymers that are employed in metal uptake $\mathrm{e}^{11,12}$. These biopolymers also trap and absorb metal sulphides and oxides ${ }^{12}$.

The use of microbial biopolymers to enhance metal removal effectiveness is emerging as a promising technique. Similarly, these polymers can survive different $\mathrm{pH}$ and temperature range $\mathrm{e}^{13}$. Their metal-binding capability depends on the producing organism, functional groups on the biopolymer, metal affinity and specificity, temperature and $\mathrm{pH}^{13-15}$. They are eco-friendly, versatile and economic compared to chemical polymers.

One of the numerous polymers of microbial origin is biosurfactant, with various applications in detergents, cosmetics, medicine, food industries, petroleum and bioremediation ${ }^{16}$. There have been various reports in literature on the metal-complexing abilities of biosurfactants in removing heavy metals from polluted soil and 


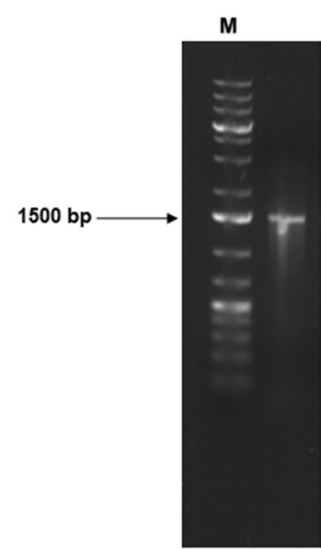

16S rRNA

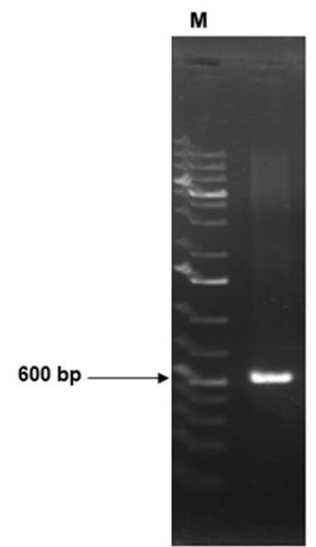

$\operatorname{cadA}$

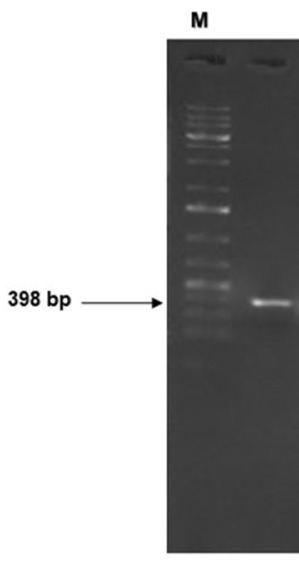

CzcD

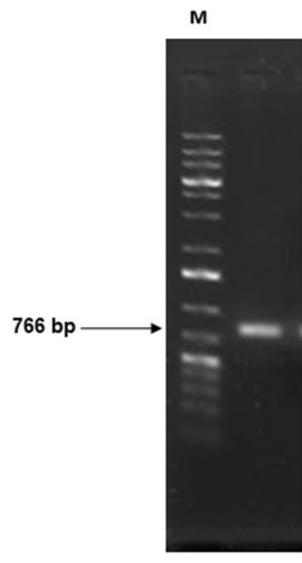

PbrA

Lane M-1kb molecular marker

Figure 1. The 16S rRNA and heavy metal resistant genes amplification of deoxyribonucleic acid (DNA) sequence of strain NWUAB01.

wastewaters ${ }^{15,17-19}$. They solubilise metal ions through increased wettability and reduced surface tension, thereby bringing metal ions out of the soil matrix ${ }^{17}$. Biosurfactants of microbial origin are good metal-complexing agents due to their stability, degradability, low toxicity and environmental compatibility ${ }^{20}$. They form stable complexes with metal ions as a result of electrostatic interaction between charged polymers ${ }^{18}$. With advances in genome sequencing, different microbial products have gained increasing attention through elucidation and prediction of biosynthetic genes.

In this study, we present the genome sequence of Bacillus cereus NWUAB01 and its underlying genetic information associated with pollutants' degradation and resistance. In addition, based on the nature of biosurfactants and their several applications in reclamation of polluted sites, their application in the removal of cadmium, chromium and lead, which have been listed among toxic elements within the first twenty pollutants priority list that are of significance to public health ${ }^{21}$ was also investigated.

\section{Results}

Strain identification, characteristics and tolerance to heavy metals. Ninety-eight heavy metal resistant bacterial isolates were isolated from the soil samples collected and one of the isolates was identified as $B$. cereus NWUAB01. Gram staining showed that the organism is Gram-positive and has a rod shape. The biochemical profile of the isolate revealed that it can ferment glucose, fructose, sucrose, and starch. It can use citrate as a carbon source, and was catalase and nitrate positive. The organism is indole and Voges-Proskaeur negative and does not ferment mannose, sorbitol, melibiose, maltose and lactose. The amplification of the $16 \mathrm{~S}$ ribosomal ribonucleic acid (rRNA) gene of strain NWUAB01 yielded the predicted $1500 \mathrm{bp}$ amplicon (Fig. 1). The amplicon sequence was compared with the 16S rRNA gene sequences in the National Centre for Biotechnology Information (NCBI) database and it showed that strain NWUAB01 had 100\% similarity with Bacillus cereus strain BS16 (MH021873), B. wiedmanni strain F23 (MF681995), B. thuringiensis strain FDB-6 (MH260380), Bacillus sp strain SP9 (MH191109) and 99\% similarity with B. proteolticus strain SPB3 (MG280785) with E-value of 0.00.

The evolutionary relationship of strain NWUAB01 was deduced using the maximum likelihood method based on the Hasegawa-Kishino-Yano model ${ }^{22}$. The phylogenetic relationship of strain NWUAB01 is presented in Fig. 2, which shows the relationship of the organism with closely related strains from the GenBank. The initial tree for the heuristic search was obtained automatically by applying the neighbour-join method. The tree is drawn to scale, with branch lengths measured in the number of substitutions per site.

The isolate showed multiple resistance to the metals tested, with the organism showing tolerance to all concentrations of $\mathrm{Pb}(100-1000 \mathrm{mg} / \mathrm{L})$ while the organism tolerated $200 \mathrm{mg} / \mathrm{L}$ of Cd and $\mathrm{Cr}$. The tolerance pattern to the tested heavy metals follows the order $\mathrm{Pb}>\mathrm{Cd}=\mathrm{Cr}$. The growth inhibition curve of strain NWUAB01 on $100 \mathrm{mg} / \mathrm{L}$ of each metal at $\mathrm{pH} 7$, agitation of $150 \mathrm{rpm}$ and $25^{\circ} \mathrm{C}$ is presented in supplementary Fig. S1. The growth rate of the organism on each of the metal tested is presented in Table S1. The highest optical density (OD) was obtained on the sixth day of growth for each of the metal tested and the control. The optical density increases with time for all metals and control (Fig. S1), with $\mathrm{Pb}$ having the least OD of 0.89, followed by Cr with OD of 0.99 after $144 \mathrm{~h}$ of growth. Cadmium had the highest OD of 1.24 after the sixth day. In summary, a decrease in the optical density of strain NWUAB01 was observed in the presence of heavy metals compared with the metal-free medium.

Genomic features of strain NWUAB01. The genome of $B$. cereus NWUAB01 was assembled into 91 contigs consisting of 5,989,415 bp and average $\mathrm{G}+\mathrm{C}$ content of $35.01 \%$. A total of 6306 genes were predicted with 87 tRNA operons and 280 pseudogenes. More features of the genome are presented in Table 1 . The circular view of the genome from PATRIC online software is presented in Fig. 3. The circular view showed the 


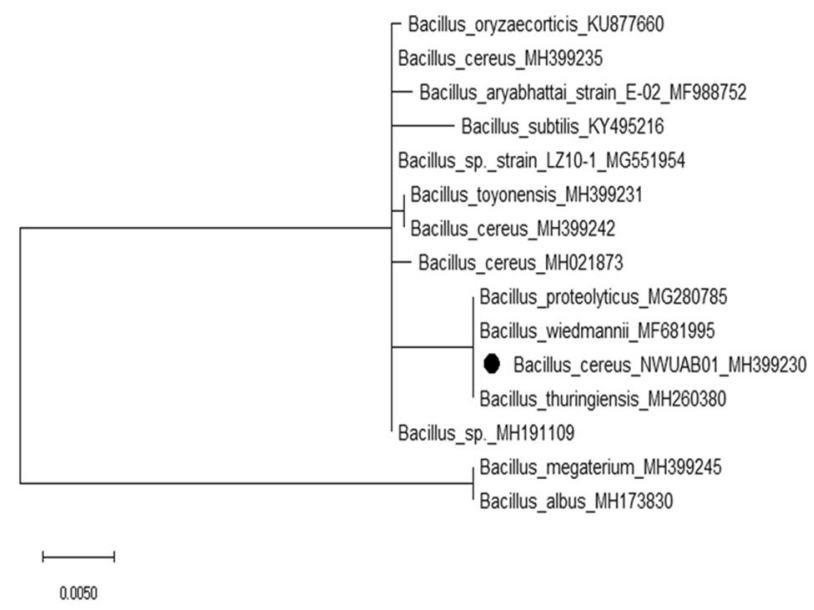

Figure 2. Phylogenetic tree using maximum likelihood method of strain NWUAB01 based on 16S rRNA gene sequence. The tree was generated using MEGAX software version 10.0.4 (Kumar et al. ${ }^{70}$ ) (https://www.megas oftware.net/resources).

\begin{tabular}{|l|l|}
\hline Gene features & Number/comment \\
\hline Genes (total) & 6306 \\
\hline CDS (total) & 6191 \\
\hline Genes (coding) & 5911 \\
\hline Genes (RNA) & 115 \\
\hline rRNAs & $11,4,8$ (5S, 16S, 23S) \\
\hline Complete rRNAs & $7(5 \mathrm{~S})$ \\
\hline Partial rRNAs & $4,4,8(5 \mathrm{~S}, 16 \mathrm{~S}, 23 \mathrm{~S})$ \\
\hline tRNAs & 87 \\
\hline Pseudo genes (total) & 280 \\
\hline Pseudo genes (ambiguous residues) & 0 of 280 \\
\hline Pseudo genes (frameshift) & 128 of 280 \\
\hline Pseudo genes (incomplete) & 130 of 280 \\
\hline Pseudo genes (internal stop) & 106 of 280 \\
\hline Pseudo genes (multiple problems) & 76 of 280 \\
\hline
\end{tabular}

Table 1. The genomic features of strain NWUAB01.

contigs, coding and non-coding features, antimicrobial resistance genes, drug targets and the $\mathrm{G}+\mathrm{C}$ content of the genome (Fig. 3). The RAST annotation categorise the genes into 27 subsystems, with genes for carbohydrate and protein metabolism, amino acid derivatives metabolism, stress response, aromatic compound metabolism, membrane transport, iron acquisition and metabolism, secondary metabolism and several others. The antiSMASH predicted the presence of 15 biosynthetic gene clusters in the genome responsible for secondary metabolite synthesis. The genes predicted include fengycin, lassopeptide, siderophore, bacillibactin, bacteriocin, lanthipeptide amongst others.

Heavy metal resistance genes. The amplification of primer-specific heavy metal-resistant genes of chromosomal DNA of strain NWUAB01 yielded amplicons of the expected band size of $600 \mathrm{bp}$ for cadA, $398 \mathrm{bp}$ for $C z c D$, and 766 bp for $P b r A$ (Fig. 1). No amplification was observed for $C z c A, C z c B, P b r T$, chrA, and $c h r B$. This might be as a result of the lack of mechanisms responsible for metal resistance in the genome of the organism. The organism may also use other mechanisms different from the efflux system for metal tolerance.

Heavy metal resistance/transport genes are abundant in the genome of strain NWUAB01, which include resistant genes encoding arsenic, cadmium, copper, cobalt and zinc as well as transport genes for chromium, cadmium, lead, magnesium and mercury (Table 2). The annotations of some of these heavy metals and their position on the genome of strain NWUAB01 are presented in Fig. 4 and Fig. S2. The large number of heavy metal-resistant genes in the genome suggests that the organism can tolerate various heavy metals. The genome search against the KEGG database through the RAST server to investigate gene functions and metabolic pathways predicted genes involved in the degradation and metabolism of xenobiotic compounds such as benzoate, fluorobenzoate, fluorine, toluene, biphenyl, naphthalene, anthracene, dichlorobenzene, atrazine, salicylate and styrene. 

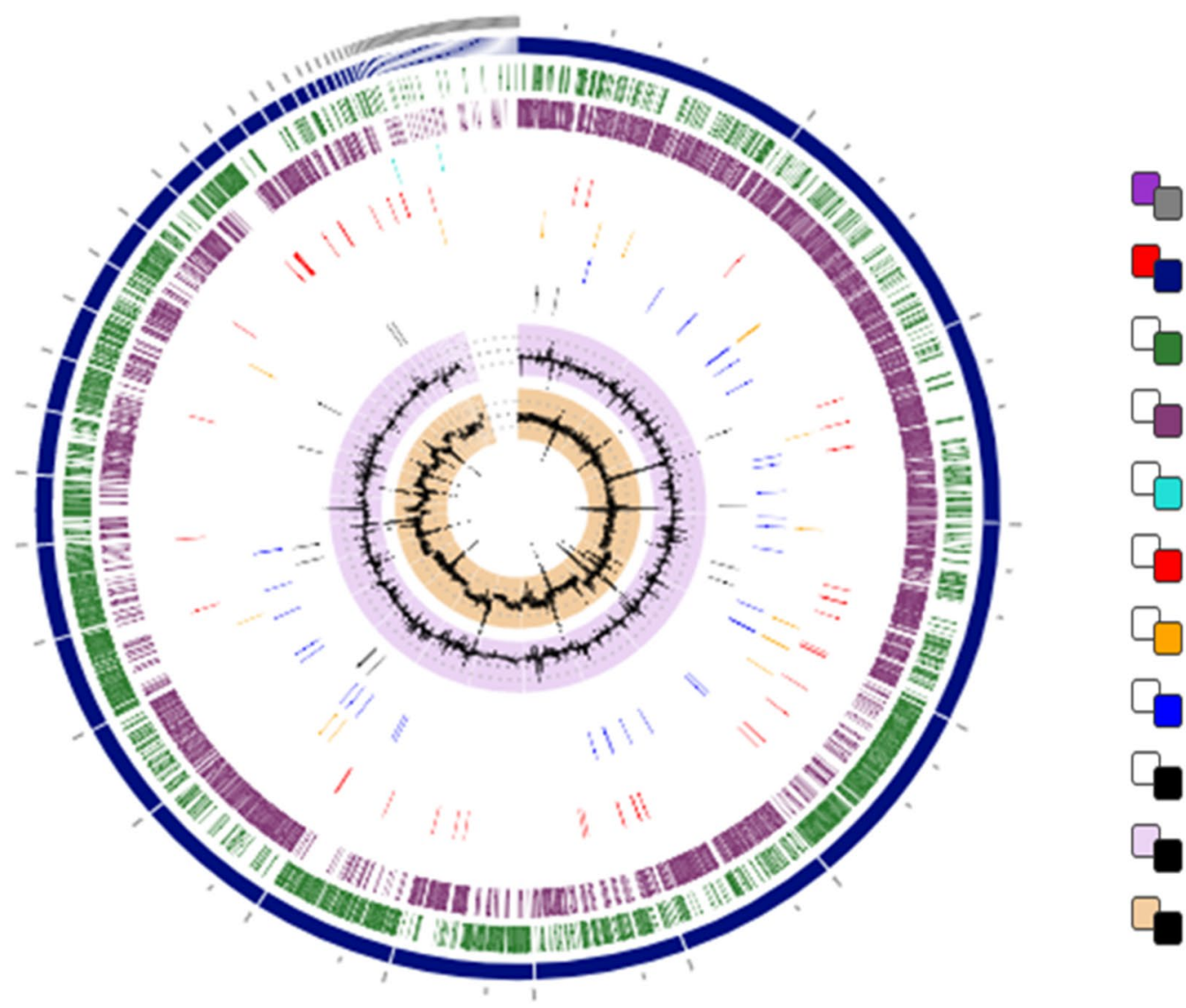

Position Label (Mbp)

Contigs/Chromosomes

CDS - FWD

CDS - REV

Non-CDS Features

AMR Genes

VF Genes

Transporters

Drug Targets

GC Content

GC Skew

Figure 3. The circular view of the genome of strain NWUAB01 with different features.

\begin{tabular}{|c|c|c|c|}
\hline Location & Product & Gene & Path way \\
\hline $26787-29154$ & Cadmium transporting ATPase & Cad & \multirow{3}{*}{ Cadmium transport } \\
\hline $29177-29555$ & Cadmium efflux system accessory protein & Cad & \\
\hline $165737-166193$ & Cadmium resistance transporter & Cad & \\
\hline $232533-233715$ & Chromate transport protein & $\operatorname{chr} A$ & Chromate reduction and transport \\
\hline $54969-55647$ & Cytoplasmic copper homeostasis protein & cutC & \multirow{2}{*}{ Copper resistance transport } \\
\hline $7803-9438$ & Copper resistance protein & CopC or CopD & \\
\hline $56097-56919$ & CorA, CorA-like magnesium transport protein & CorA & \multirow{2}{*}{ Magnesium transport } \\
\hline $85440-86403$ & Magnesium transport protein & CorA & \\
\hline $38243-39143$ & Cobalt-zinc-cadmium resistance protein & $C z c D$ & Cadmium, cobalt and zinc transport \\
\hline $192511-193837$ & Arsenic efflux pump protein & - & \multirow{3}{*}{ Arsenate reduction and transport } \\
\hline $43673-44069$ & Arsenate reductase family protein & - & \\
\hline $45426-45831$ & Arsenical resistance protein ACR3 & - & \\
\hline $12198-13494$ & Manganese transport protein & MntH & Manganese transport \\
\hline $12769-14695$ & $\begin{array}{l}\text { Lead, cadmium, zinc and mercury transporting } \\
\text { ATPase }\end{array}$ & - & Lead, cadmium, zinc and mercury transport \\
\hline $19421-20372$ & Zinc $\mathrm{ABC}$ transporter, periplasmic binding protein & $Z n u A$ & Zinc transport \\
\hline
\end{tabular}

Table 2. Heavy metal resistant and transport genes with their location on the genome of NWUAB01.

Biosurfactant production and characterisation. The genome of strain NWUAB01 revealed the Wzx (O-antigen flippase) and Wzy (oligosaccharide repeat unit polymerase) genes on location 204798-206235 and 203580-204795 respectively (Fig. S3). The genes are responsible for the production of extracellular polymer using the Wzx/Wzy-dependent pathway in strain NWUAB01.

The emulsification of different hydrocarbons and vegetable oil by strain NWUAB01 is presented in Fig. S4 and the biosurfactant properties of the organism are presented in Table 3. The organism was able to haemolyse red blood cells ( $\alpha$-hemolysis), was positive for drop collapse and reduced the surface tension of the growth medium 
a
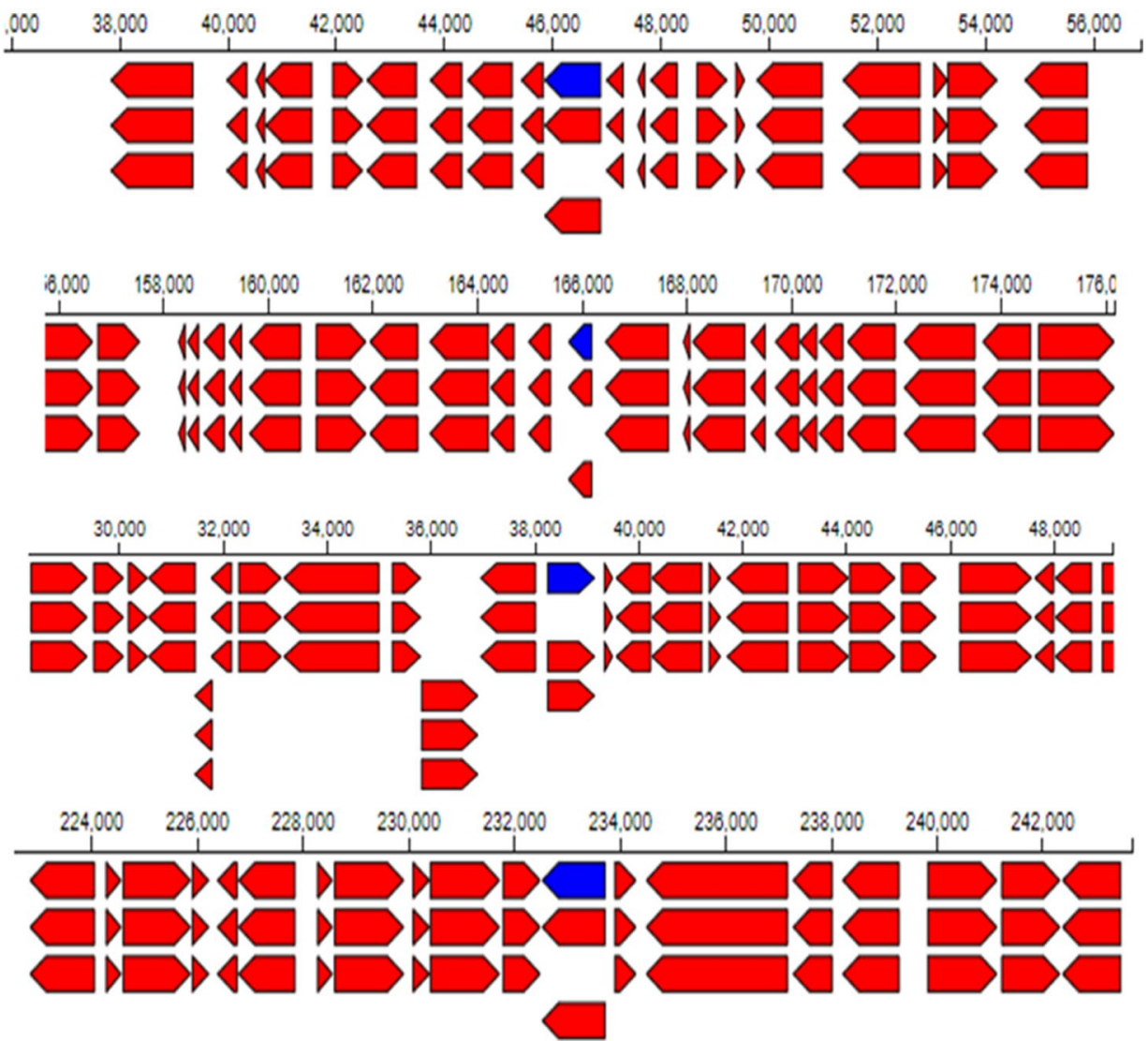

Figure 4. The annotation of heavy metal resistant genes on the genome of strain NWUAB01 and their location on the genome (a) arsenic resistance protein (b) cadmium resistance transporter (cad) (c) cobalt-zinc-cadmium resistance protein $(C z c D)$ and $(\mathbf{d})$ chromate transport protein $(c h r A)$.

\begin{tabular}{|c|c|c|}
\hline \multicolumn{2}{|l|}{ Test } & Result \\
\hline \multicolumn{2}{|l|}{ Haemolysis test } & Positive \\
\hline \multicolumn{2}{|l|}{ Oil displacement } & Negative \\
\hline \multicolumn{2}{|l|}{ Drop collapse } & Positive \\
\hline \multicolumn{2}{|l|}{ Surface tension } & $39.5 \pm 0.25 \mathrm{mN} / \mathrm{m}$ \\
\hline \multirow{4}{*}{ Emulsification index $\left(\mathrm{E}_{24}\right)(\%)$} & Engine oil & $54.0 \pm 0.58$ \\
\hline & Hexadecane & $22.4 \pm 0.60$ \\
\hline & Kerosene & $37.5 \pm 0.29$ \\
\hline & Vegetable oil & $24.0 \pm 0.58$ \\
\hline Biosurfactant yield & & $0.38 \mathrm{~g} / \mathrm{L}$ \\
\hline
\end{tabular}

Table 3. Evaluation of $B$. cereus NWUAB01 for biosurfactant production. Values are means of triplicate readings \pm standard error.

to $39.48 \mathrm{mN} / \mathrm{m}$ (Table 3). Strain NWUAB01 produced stable emulsions with various hydrocarbons and vegetable oil with the highest $\mathrm{E}_{24}$ of $54 \%$ with engine oil and lowest $\mathrm{E}_{24}$ of $22 \%$ with hexadecane at room temperature and pH 7 (Table 3). The stability of the emulsion produced by strain NWUAB01 was tested at different temperatures and $\mathrm{pH}$ (Fig. S5). At $40{ }^{\circ} \mathrm{C}$, the organism gave a stable emulsion with $\mathrm{E}_{24}$ of $54 \%, 30 \%, 22 \%$ and $20 \%$ for engine oil, kerosene, hexadecane and vegetable oil respectively (Fig. S5). A reduction in the stability of the emulsion was observed at the extreme temperature and $\mathrm{pH}$. The scanning electron micrograph (SEM) of the surfactant produced by strain NWUAB01 is presented in Fig. S6, which shows the morphology of the surfactant.

Spectroscopic characterisation. Fourier transform infrared spectroscopy (FTIR) characterisation of biosurfactant produced by strain NWUAB01 is presented in Fig. 5. The spectrum had a characteristic absorbance band of peptides at $3273 \mathrm{~cm}^{-1}$ (stretching mode $\mathrm{N}-\mathrm{H}$ ), $1624 \mathrm{~cm}^{-1}$ (stretching mode CO-N) and $1526 \mathrm{~cm}^{-1}$ (N-H deformation and C-N stretching mode). The bands obtained at $2961-2878 \mathrm{~cm}^{-1}$ and $1624-1447 \mathrm{~cm}^{-1}$ 


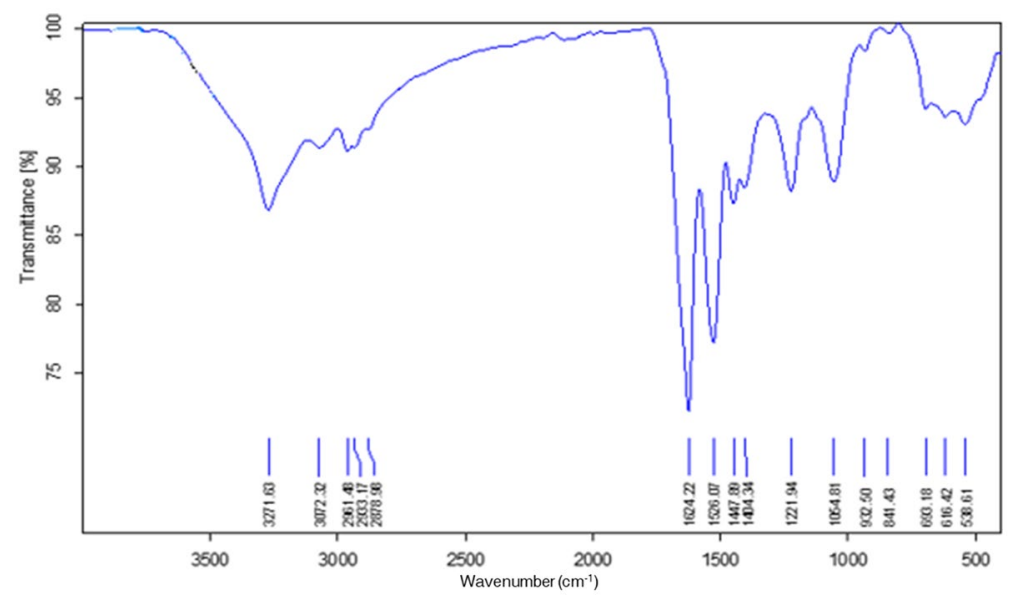

Figure 5. The FTIR spectra of biosurfactant produced by strain NWUAB01.

represent the presence of aliphatic chains. The absorption around the region $1624 \mathrm{~cm}^{-1} \mathrm{can}$ be attributed to the lactone carbonyl absorption. The surfactant contains peptide-like moieties. The spectroscopic analysis showed that the biosurfactant is a lipopeptide homolog with different fatty acid chain lenght. The MALDI-TOF spectrum of the surfactant produced by strain NWUAB01 is shown in Fig. S7. There are only well-resolved groups of peaks at $\mathrm{m} / \mathrm{z}$ values between 182.76 and 696.37 .

Heavy metal removal from contaminated soil. We observed that the biosurfactant was capable of removing $69 \%$ of $\mathrm{Pb}, 54 \%$ of $\mathrm{Cd}$ and $43 \%$ of $\mathrm{Cr}$ from the batch experiment from the initial concentration of $100 \mathrm{mg} / \mathrm{L}$ (Table S2). The strain removed $83 \%$ of $\mathrm{Pb}, 60 \%$ of Cd and $30 \%$ of Cr from polluted soil (Table S2). We found that the biosurfactant produced by strain NWUAB01 is efficient in removing metal from contaminated soil. The results of this study showed that $\mathrm{Pb}$ has the highest removal followed by $\mathrm{Cd}$ and $\mathrm{Cr}$.

\section{Discussion}

Soils polluted with heavy metals are usually sources of organisms resistant to metals ${ }^{23,24}$. Mining soils are rich sources of potential bacterial population resistant to heavy metals, but with reduced bacterial diversity, population size and metabolic activities ${ }^{25}$. Metal resistance might have evolved due to the presence of heavy metals in their growth medium ${ }^{26}$. In this study, soil samples from a gold-mining environment, with natural occurrence of heavy metals, were used for isolating strain NWUAB01, which is consistent with the studies of Oladipo et al. ${ }^{27}$ and Reith et al. ${ }^{28}$ that isolated $B$. cereus from gold mining soil. Thus, the metal-containing environment might have led to the evolvement of mechanisms of resistance to heavy metals in the organism.

Elevated level of tolerance to metals is an important criterion for metal removal by bacterial strains ${ }^{23}$ and strain NWUAB01 showed multiple tolerance to the metals tested and good preliminary metal removal properties, with the ability to grow on all concentrations of $\mathrm{Pb}$ tested and on $200 \mathrm{mg} / \mathrm{L}$ of Cd and Cr. The organisms showed the ability to withstand varying metal concentrations as reported in different studies ${ }^{29,30}$ from different polluted sites and higher tolerance compared to those observed by Oladipo et al. ${ }^{27}$. Varied responses of strain NWUAB01 to different metal ions observed in this study could be attributed to different modes of action, unique chemistry and level of toxicity of each metal ${ }^{27,31}$.

Multi-metal resistance by microbial strains gives mutual benefits to the single component and is suitable for metal removal ${ }^{32}$. Multi-metal resistance shows various combinations of genetic determinants for metal resistance. This could have probably evolved in the natural environment of the organism. The genetic determinants encode specific metal transport proteins involved in the sequestration of metal ions and regulating active efflux ${ }^{33}$. The resistance pattern of strain NWUAB01 to the tested metals showed that the organism tolerated $\mathrm{Pb}$ than $\mathrm{Cd}$ and Cr. Many reports have also reported many bacteria with multi-metal resistance abilities ${ }^{23,34,35}$. Multi-metal tolerance in Bacillus species has been well documented.

Various mechanisms are employed by microbial cells for metal removal ${ }^{10}$. These include bioaccumulation, biomineralisation, biosorption and biotransformation. The growth kinetics of the organism on different metal revealed that the OD increases with time for all metals and control. The growth rate of strain NWUAB01 on exposure to metal-enriched medium varied with each tested metal. The growth rate was enhanced in the presence of $\mathrm{Pb}$, while there was a reduced growth rate in the presence of $\mathrm{Cr}$. The same pattern of growth rate was observed for $\mathrm{Cd}$ and the control. Similarly, the generation time in $\mathrm{Pb}$-medium was lower than that of $\mathrm{Cd}, \mathrm{Cr}$ and the control. This shows that the doubling time was faster in $\mathrm{Pb}$-medium, which also has a higher number of generations, compared to $\mathrm{Cr}$, $\mathrm{Cd}$ and the control. This is an indication that $\mathrm{Cd}$ and $\mathrm{Cr}$ toxicity to strain NWUAB01 may be dose-dependent ${ }^{27}$. Increased generation time is usually observed for environmental constraint. However, generation time depends on all factors influencing growth, thus growth rate can vary considerably between the different experimental setups. A decrease in the OD of strain NWUAB01 was observed in the presence of heavy metals compared with the metal-free medium. This is similar to the pattern observed by Shim et al..$^{30}$ and Raja et $\mathrm{al}^{36}$. The decrease in the growth of $B$. cereus in the presence of heavy metals might be due to the metal ion 
interaction with the cell membrane, which increases metal-binding sites and makes it less effective for the transport of materials essential for growth ${ }^{37}$. To understand the mechanism of resistance to metals, growth kinetics is used as an index of adaptation to external constraints ${ }^{27}$. The inverse growth rate relationship observed between metal concentrations and growth rate in tolerant bacteria are characteristics of bacterial growth in response to external stress ${ }^{38}$. The low inhibitory values obtained for $\mathrm{Cd}$ and $\mathrm{Cr}$ along with a decrease in growth rate in the presence of these metals could be attributed to the decline in efficiency of substrate utilisation as a result of high energy cost of the organism subjected to metal stress ${ }^{39}$.

The presence of extracellular substances, which serve as a barrier in Gram-positive bacteria enhances metal resistance compared to Gram-negative organisms ${ }^{40}$. A direct comparison of metal resistance by strain NWUAB01 with other studies is difficult due to the composition and strength of the medium, the nature of the medium that influences metal bioavailability, complexation, organic constituents, diffusion rate and incubation period, which cause variations in inhibitory concentrations ${ }^{30,41}$.

Genes encoding metal resistance can eliminate or reduce metal toxicity ${ }^{42}$. Hence, strain NWUAB01 was screened for metal-resistant genes. The amplification of primer-specific heavy metal-resistant genes of chromosomal DNA of strain NWUAB01 yielded amplicons of the expected band size for $c a d A, C z c D$, and $P b r A$. cadA, which is a P-type ATPase, was also found to be present on the organism. cadA is cadmium-specific ATPase used for Cd efflux and confers metal resistance to strain NWUAB01. $C z c D$ is responsible for the efflux of cobalt, zinc and cadmium. Both $C z c D$ and $c a d A$ operons are energy-dependent efflux systems that confer cadmium resistance ${ }^{43}$. The efflux systems are actively involved in the pumping out of toxic metal ions that enter the cell through ATPase diffusion. PbrA is the protein responsible for lead uptake and down-regulation of the metal concentration, which occurs in response to high levels of lead ${ }^{44}$. It thus revealed that isolate NWUAB01 has a functional gene that is key in lead resistance. $\mathrm{PbrA}$ is an active efflux pump protein that transports $\mathrm{Pb}$ ions against the concentration gradient using energy provided by ATP hydrolysis ${ }^{42}$. Metal transport proteins are involved in transporting metal ions outside the cell membrane ${ }^{45}$. These metal transporting proteins are a group of PIB-type ATPases, which governs metal resistance. $c a d A, C z c D$ and $P b r A$ belong to these groups of proteins present in strain NWUAB01 which are involved in metal resistance. These proteins prevent metal accumulation of highly reactive and toxic metals within the cell membrane and play a key role in metal resistance by strain NWUAB0 $1^{45}$. No amplification was observed for $C z c A, C z c B, P b r T$, $\operatorname{ch} r A$, and $\operatorname{chr} B$. This might be as a result of the lack of mechanisms responsible for metal resistance in the genetic system of the organism. The organism may also use other mechanisms different from the efflux system for metal tolerance.

However, heavy metal resistance/transport genes are abundant in the genome of $B$. cereus NWUAB01, which include several resistance genes encoding arsenic, cadmium, copper, cobalt and zinc as well as transport genes for chromium, cadmium, lead, magnesium and mercury. The abundant metal-resistant genes in the genome of strain NWUAB01 suggest that the organism can tolerate different metals, which is consistent with a previous report demonstrating the uptake and heavy metal resistance in $B$. cereus ${ }^{28}$. The organism uses different genomemediated resistance mechanisms such as the transport proteins and efflux pump to survive heavy metal stress. The genome also revealed genes involved in the degradation and metabolism of xenobiotic compounds.

The production of different biosynthetic gene clusters and metabolism of different compounds are adaptive mechanisms for surviving diverse ecological niches ${ }^{9}$, which can be harnessed for different environmental and industrial purposes. The synthesis of biopolymers in bacteria occurs through four pathways namely: ATPbinding cassette transporter-dependent, extracellular synthesis using sucrase protein, Wzx/Wzy-dependent, and synthase-dependent pathways ${ }^{46,47}$. Bacteria using the Wzx/Wzy dependent pathway carry the flippase (Wzx) and polymerase (Wzy) gene in their extracellular polysaccharide operons ${ }^{47}$. The presence of the Wzx $(\mathrm{O}$-antigen flippase) and Wzy (oligosaccharide repeat unit polymerase) gene in the genome of strain NWUAB01 signified the production of extracellular polymer using the Wzx/Wzy-dependent pathway. This pathway produced polymers of various sugar components that results in heteropolysaccharide production ${ }^{47}$.

Blood agar has been used to quantify and screen for biosurfactant production by bacteria ${ }^{48,49}$. Carrillo et al..$^{50}$ and Kumar et al. ${ }^{49}$ found an association between the surfactant production and haemolytic activity, and recommend blood lysis as screening method for the biosurfactant production. Although the lysis of erythrocytes could exclude some biosurfactant producing organisms, it has helped in initial screening of biosurfactant producing organisms. Strain NWUAB01 showed complete haemolysis on erythrocytes and was used as the initial screening test for its selection. The reduction in surface tension of water has been reported in several studies ${ }^{49,51,52}$ for various biosurfactant producing Bacillus species. The reduction in surface tension confirmed the production of biosurfactant by strain NWUAB01. The ability to reduce the surface tension of water from 72 to $35 \mathrm{mN} / \mathrm{m}$ has been considered as a characteristic of a good surfactant ${ }^{18}$. Strain NWUAB01 has a surface tension that is similar to that produced by $B$. cereus NK1, which has a value of $38 \mathrm{mN} / \mathrm{m}^{51}$. It has a better surface tension than $B$. cereus, B. sphaericus and $B$. fusiformis, with surface tension of $50,55.2$ and $56.4 \mathrm{mN} / \mathrm{m}$ respectively ${ }^{53}$, and $B$.

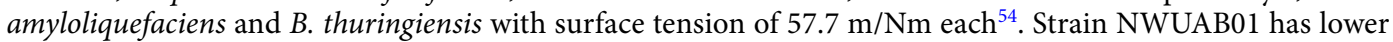
surface tension potential compared to Bacillus sp reported by Heryani and Putra ${ }^{55}$, that had a value of $27.1 \mathrm{mN} / \mathrm{m}$. The differences in the surface tension values can be attributed to different production medium, conditions of growth and uniqueness of individual organisms.

The emulsification index is another criterion used in the selection of surface-active-producing bacterial isolates. Satpute et al. ${ }^{56}$ suggested that more than one screening method should be used in the primary screening of potential surface-active agents. Strain NWUAB01 produced stable emulsions with various hydrocarbons and vegetable oil. This appreciable emulsifying property made the organism a suitable surface-active agent. The ability of biosurfactant to emulsify different hydrocarbons and vegetable oil had been reported for Bacillus species with different results. Sriram et al. ${ }^{51}$ reported B. cereus NK1 to emulsify motor oil, diesel oil, crude oil, petrol and vegetable oil with $\mathrm{E}_{24}$ of $80.36 \%, 55.5 \%, 70 \%, 44 \%$ and $50.47 \%$ respectively. Strain NWUAB01 had lower emulsification index compared to what was reported for B. cereus NK1. Likewise, Barakat et al. ${ }^{54}$ reported 
emulsification index of $60 \%$ and $69 \%$ with paraffin oil for B. amyloliquefaciens and B. thuringiensis respectively. This might be as a result of the different components of the production medium and different carbon sources used for producing biosurfactant ${ }^{57}$.

The production of biopolymers that confer resistance to microorganism growing in polluted environments is an important defence mechanism against environmental stress and for survival ${ }^{20}$. Biosurfactants are applied in several fields and their application depends on their stability at different temperatures and $\mathrm{pH}^{58}$. Reduction in the stability of the emulsion was observed at the extreme temperature and $\mathrm{pH}$. As the $\mathrm{pH}$ increases, there was an increase in the stability of the emulsion until $\mathrm{pH} 7$, after which the stability begins to reduce. The result indicated that an increase in $\mathrm{pH}$ had a positive effect on the stability of the emulsion. This could be as a result of the precipitation of biosurfactant at high $\mathrm{pH}$ values ${ }^{58}$. Lower stability at reduced $\mathrm{pH}(<4)$ can be attributed to distortion of the biosurfactant structure and precipitation ${ }^{59}$.

The FTIR characterisation of the biosurfactant produced by strain NWUAB01 suggested that the surfactant produced by strain NWUAB01 contained peptide-like moieties, which is typical of lipopeptide surfactants produced by Bacillus species described in literature ${ }^{51,57,60}$. The MALDI-TOF spectra of the detected groups could be attributed to the iturin variants as described by Jasim et al.$^{61}$ and Cho et al. ${ }^{62}$. The lack of specific iturin homologs can be attributed to the loss of some of the amino acids such as asparagine, glycine and tyrosine in the structure of iturin, which makes many homologs of the lipopeptide difficult to identify ${ }^{63}$. The composition of the medium of production of lipopeptides can be attributed to some of the variations in the structure ${ }^{64}$. This showed that different compounds could be expressed by Bacillus species during changes in growth condition ${ }^{63}$.

Biosurfactant soil washing has been used for metal removal from polluted soils and sediments due to their biodegradability, low toxicity and eco-friendly nature ${ }^{18,65}$. In this study, we evaluated the metal removal capability of biosurfactant produced by strain NWUAB01. We found that the biosurfactant produced by strain NWUAB01 is efficient in removing metal from contaminated soil. In a multi-metal system, the percentage removal of each metal decreases compared to a single metal system. The ability of the biosurfactant to remove metals from contaminated soil was also examined in comparison with strain NWUAB01. We observed that the percentage metal removal was higher for the organism than the surfactant. The results of this study showed that $\mathrm{Pb}$ has the highest percentage removal followed by $\mathrm{Cd}$ and $\mathrm{Cr}$. This could be due to the affinity of the biosurfactant to different metals ${ }^{66,67}$. The efficiency of metal removal by biosurfactants also depends on the type of biosurfactant and its concentration, soil characteristics and other additives such as acids and bases that may be added ${ }^{67}$. Metal removal efficiency of strain NWUAB01 biosurfactant is higher than those reported by Singh and Cameotra ${ }^{65}$. However, the metal removal efficiency of lipopeptide of marine origin reported by Das et al. ${ }^{1}$ was higher than that of strain NWUAB01. The metal removal potential of strain NWUAB01 corroborated the work of Mulligan et al. ${ }^{68}$, who reported the use of lipopeptide from B. subtilis for the removal of $\mathrm{Cd}, \mathrm{Cu}$ and $\mathrm{Zn}$. Lipopeptides, which are anionic in nature, have better metal sequestration properties and are more effective in metal removal ${ }^{18}$. Removal of metals by biosurfactant has been proposed to occur by surfactant sorption to the soil surface, followed by complexation with metals; thus leading to metal detachment from soil surface by the reduction in the interfacial tension ${ }^{18}$.

In conclusion, the findings in this study showed that strain NWUAB01 is metabolically versatile with high heavy metal affinity that can be harnessed for industrial applications. The presence of diverse metal transport/ resistant genes and xenobiotic compounds degradation revealed the ability to survive in varied ecological niches. This study also demonstrated the potential of the biosurfactant produced by strain NWUAB01 for effective removal and recovery of heavy metals for environmental applications.

\section{Materials and methods}

Isolation and screening of metal-resistant bacterial isolates. Soil samples used in this study were obtained from a gold mining area in Vryburg, South Africa (Table S3 and Fig. S8). The soil samples were collected at a depth of $10-30 \mathrm{~cm}$ in triplicate and transported to the laboratory for analysis in sterile plastic bags. Control soil samples were collected few kilometres away from the mine (Table S3 and Fig. S8). The concentration of heavy metals from each sampling site is also presented in the supplementary Table S3. The method of Rajkumar and Freitas ${ }^{69}$ was used in isolating resistant bacteria. Serially diluted soil $(1 \mathrm{~g})$ samples were plated on Luria-Bertani (LB) agar supplemented with $50 \mathrm{mg} / \mathrm{L}$ of heavy metal solutions ( $\mathrm{CdSO}_{4}$ (Sigma-Aldrich, India), $\mathrm{K}_{2} \mathrm{CrO}_{4}$ and $\mathrm{Pb}\left(\mathrm{NO}_{3}\right)_{2}$, (Sigma-Aldrich, USA)), with each metal at a time ${ }^{69}$. The metal solutions were filter-sterilized through a $0.22 \mu \mathrm{m}$ filter membrane before they were added to sterile molten LB agar. After that, the plates were incubated for $48 \mathrm{~h}$ at $37^{\circ} \mathrm{C}$. Metal-resistant isolates were screened for tolerance to different concentrations ( 100 to $1000 \mathrm{mg} / \mathrm{L}$ ) of each heavy metal on LB agar ${ }^{69}$. The organisms were grown on LB agar containing different concentrations of metals from 100 to $1000 \mathrm{mg} / \mathrm{L}$. The plates were incubated for $48 \mathrm{~h}$ at $37^{\circ} \mathrm{C}$ and observed for growth. Metal sorption by strain NWUAB01 was performed with $100 \mathrm{mg} / \mathrm{L}$ of each metal and growth was monitored by measuring OD at $600 \mathrm{~nm}$ against the blank at $24 \mathrm{~h}$ intervals using a UV spectrophotometer (Thermo Spectronic, Merck, South Africa) as described by Oladipo et al. ${ }^{27}$ with little modification. A 24-h old culture (approximately $10^{6} \mathrm{CFU} / \mathrm{mL}$ ) in LB broth was used as the inoculum. This was performed in $200 \mathrm{~mL}$ Erlenmeyer flask. Briefly, each flask contained a final volume of $100 \mathrm{~mL}$, comprising $98 \mathrm{~mL}$ of sterile LB broth, $1 \mathrm{~mL}$ of the inoculum and $1 \mathrm{~mL}$ of filter sterilized metal solution. Experimental control and blank were also setup. The control comprised $98 \mathrm{~mL}$ of LB broth and $1 \mathrm{~mL}$ inoculum of the isolate, while the blank contained $98 \mathrm{~mL}$ LB broth.

Identification of strain NWUAB01. Strain NWUAB01 was identified using the following biochemical tests: Gram reaction, sugar fermentation test (fructose, glucose, galactose, lactose, starch, sorbitol, sucrose, maltose, and mannitol), oxidase, catalase test, hydrogen sulphide production, citrate utilisation, methyl red, nitrate reduction, indole production, and Voges-Proskauer test. 
The DNA of the isolate was extracted using ZR soil microbe DNA extraction kit (Zymo Research, CA, USA) as described in the manufacturer's protocol. The quantity and quality of the DNA was determined using NanoDrop Lite spectrophotometer (Thermo Fischer Scientific, CA, USA).

16S rRNA characterisation and heavy metal-resistant gene determination. The primer sets used for 16S rRNA gene amplification of strain NWUAB01 are described in the supplementary Table S4. All primer sets were synthesised by Whitehead Scientific, Cape Town, South Africa. A total volume of $25 \mu \mathrm{L}$ of a reaction mixture of forward and reverse primer $(0.5 \mu \mathrm{L}$ of each), DNA template $(1 \mu \mathrm{L}), 2 \mathrm{X}$ master mix $(12.5 \mu \mathrm{L})$ (Biolab, England), and $11 \mu \mathrm{L}$ nuclease free water was used for the Polymerase Chain Reaction (PCR). PCR was performed using a thermal cycler (Bio-Rad, CA, USA) and the PCR products were analyzed on $1 \%(\mathrm{w} / \mathrm{v}$ ) agarose gel supplemented with $10 \mu \mathrm{L}$ ethidium bromide and electrophoresed. One kilobase molecular marker was used to determine the band size of the amplicons. The amplicons were sequenced at Inqaba Biotech, Pretoria, South Africa.

The sequences obtained were processed and nucleotide BLAST was performed using NCBI GenBank database to determine the evolutionary relatedness of the strain. Molecular Evolutionary Genetics Analysis (MEGAX) software $^{70}$ was used for sequence alignment and the construction of phylogenetic tree. The phylogenetic tree was constructed based on the 16S rDNA using the maximum parsimony method. The sequence was deposited in the NCBI GenBank database.

Strain NWUAB01 was screened for heavy metal resistance genes using primers encoding for chromium ( $c h r A$ and $c h r B$ ), cadmium $(C z c D, C z c B, C z c A$, and $c a d A)$, and lead $(P b r A$ and $P b r T)$. The primer sets and their corresponding PCR conditions are presented in Table S4.

Whole-genome sequencing of strain NWUAB01. Whole-genome sequencing of strain NWUAB01 was performed as described by Babalola et al. ${ }^{71}$. The genome was sequenced on the Illumina Miseq platform. The DNA sample (50 ng) was fragmented by ultrasonication procedure (Covaris), and the fragments selected by size with AMPure XP beads and the ends were repaired. Adapter sequences were ligated to each fragment. The fluorometric method was used for quantification of the fragment and then diluted to a concentration of $4 \mathrm{nM}$. A MiSeq v3 kit was used for sequencing of the fragments. Genome sequencing of strain NWUAB01 was performed at Inqaba Biotec, Pretoria, South Africa.

The obtained sequences were processed and the quality of the reads were checked using FastQC v.1.0.1 of the KBase platform ${ }^{72}$. The reads were trimmed to filter the low quality and adapter sequences using Trimmomatic v0.36 $6^{73}$. SPAdes v.3.12.0 $0^{74}$ was used for de novo assembly. The NCBI Prokaryotic Genome Annotation Pipeline $(\mathrm{v} 4.7)^{75}$ and Rapid Annotations using Subsystems Technology (RAST v2.0) ${ }^{76}$ were used for genome annotation. Biosynthetic gene clusters were detected with antiSMASH v5.1.077. The circular view of the genome was created using PATRIC v3.5.43

Biosurfactant production and characterisation. The pure strain of NWUAB01 was used to quantify the biosurfactant production by different methods, which include haemolytic activity, drop collapse test, oil displacement test, and emulsification activity. All tests were conducted in triplicate. The haemolytic test on blood agar was performed using the method described by Bicca et al. ${ }^{48}$.

The cultivation medium for biosurfactant production contains $(\mathrm{g} / \mathrm{L})$ : yeast extract, 0.5 ; sucrose, 5.0 ; $\mathrm{Na}_{2} \mathrm{HPO}_{4} \cdot 12 \mathrm{H}_{2} \mathrm{O}, 1.4 ; \mathrm{MgSO}_{4} \cdot 7 \mathrm{H}_{2} \mathrm{O}, 0.02 ; \mathrm{KH}_{2} \mathrm{PO}_{4}, 0.4$ and peptone, $20.0^{51}$. The medium was seeded with $3 \%$ inoculum prepared from LB broth into $50 \mathrm{~mL}$ cultivation medium in a $250 \mathrm{~mL}$ Erlenmeyer flask and incubated at $37^{\circ} \mathrm{C}$ for 7 days at $160 \mathrm{rpm}$. All readings were taken with supernatant obtained by centrifuging the cultures at $10,000 \mathrm{rpm}$ for $20 \mathrm{~min}$.

The drop collapse test was determined as described by Sriram et al. ${ }^{51}$. Mineral oil $(2 \mu \mathrm{L})$ was added to each well of a 96 -well microtiter plate and allowed to equilibrate for one hour at $37^{\circ} \mathrm{C}$. After that, $5 \mu \mathrm{L}$ of the culture supernatant was added to the centre of each well over the oil layer. After one minute, the shape of the oil drop was examined. A flattened drop was recorded as positive for biosurfactant production. Water was used as a negative control.

The oil displacement test was performed as described by Sriram et al..$^{51}$. A Petri dish (150 mm diameter) was filled with $40 \mathrm{~mL}$ sterile distilled water and engine oil $(15 \mu \mathrm{L})$ was added. After that, $10 \mu \mathrm{L}$ of the supernatant was added to the centre of the oil film and the halo zone was measured after $30 \mathrm{~s}$ of incubation.

The emulsification activity of strain NWUAB01 was determined by measuring the emulsification index $\left(\mathrm{E}_{24}\right)$ after $24 \mathrm{~h}$. A $2 \mathrm{~mL}$ volume of the culture supernatant was added to $2 \mathrm{~mL}$ of kerosene in a test tube and the mixture was vortexed at high speed for $2 \mathrm{~min}$. The $\mathrm{E}_{24}$ was calculated as the percentage of the height of emulsified layer divided by the total height of the liquid column ${ }^{20}$. The test was also performed using engine oil, hexadecane and vegetable oil in place of kerosene. The stability of the emulsion produced was determined at different temperatures and $\mathrm{pH}$. Surface tension of the supernatant was measured at room temperature with a force tensiometer (Sigma 702, Biolin Scientific, Sweden) using the du Nouy ring method.

The biosurfactant produced was extracted and purified as described by Gond et al. ${ }^{79}$. Strain NWUAB01 was grown in $1 \mathrm{~L}$ cultivation medium for 7 days at $37^{\circ} \mathrm{C}$ at $200 \mathrm{rpm}$. The cell free supernatant obtained by centrifuging at $5000 \mathrm{rpm}$ for $15 \mathrm{~min}$ at $4{ }^{\circ} \mathrm{C}$ was precipitated by adding $\mathrm{HCl}$ to reduce the $\mathrm{pH}$ to 2 and incubated overnight at $4{ }^{\circ} \mathrm{C}$. The precipitate was collected by centrifugation at $10,000 \mathrm{rpm}$ for $15 \mathrm{~min}$ at $4{ }^{\circ} \mathrm{C}$ and dissolved in methanol and then filtered using a membrane filter $(0.22 \mu \mathrm{m}$ PTFE) to remove cell components and large particles. The resulting mixture was then concentrated using a vacuum evaporator at $30^{\circ} \mathrm{C}$ and lyophilised. The lyophilised biosurfactant was characterised by FTIR. The spectrum was collected from 400 to 4000 wavenumbers $\left(\mathrm{cm}^{-1}\right)$ with a resolution of $4 \mathrm{~cm}^{-1}$ at an average of 32 scans using an Alpha II Platinum-ATR IR spectrometer (Brucker, USA). 
The lyophilised biosurfactant was also subjected to scanning electron microscope (JSM-6390LV, JEOL, Japan). The molecular mass of the surfactant was determined using Micromass ToFSpec matrix-assisted laser desorption ionization time-of-flight mass spectrometry (MICRO-TOF-MS). Applied Biosystems 4800 Plus MICRO-TOF/ TOF analyzer (AB Sciex, USA) was used to obtain a purified sample. The analyzer was operated in the positive ion mode with $337 \mathrm{~nm}$ nitrogen laser for ionization, accelerating voltage of $20 \mathrm{kV}$ and a-cyano-4-hydroxycinnamic acid for matrix. The molecular weight was determined by mass spectrum smart formula tools and the mass spectrometry was determined using the Bruker compass data analysis.

Remediation of heavy metal-contaminated soil with biosurfactant. Biosurfactant washing of heavy metal-polluted soil was performed in a batch experiment as described by Singh and Cameotra ${ }^{65}$. A gram of heavy metal $(100 \mathrm{mg} / \mathrm{L}$ of each metal salt) contaminated soil sample was placed in a $50 \mathrm{~mL}$ centrifuge tube with $25 \mathrm{~mL}$ of $0.5 \mathrm{~g} / \mathrm{L}$ of purified biosurfactant. The soil samples used were uncontaminated soil samples supplemented with $100 \mathrm{mg} / \mathrm{L}$ of each metal salt. The experiment was performed at room temperature and $\mathrm{pH} 7$. The mixture was centrifuged at $5000 \mathrm{rpm}$ for $15 \mathrm{~min}$ and the supernatant was filtered. The metal composition of the filtered supernatant was analyzed by ICP-OE Spectrometry (Agilent Technologies, Palo Alto, CA, USA). The positive control used is strain NWUAB01, while sterile distilled water served as the negative control. The metal removal efficiency was calculated using the formula:

$$
\text { Removalrate }(\%)=\frac{C i-C e}{C i} \times 100
$$

where $\mathrm{C}_{\mathrm{i}}$ and $\mathrm{C}_{\mathrm{e}}$ are the initial and final concentrations of each metal respectively.

Ethical approval. This article does not contain any studies with human participants or animals performed by any of the authors.

\section{Data availability}

B. cereus NWUAB01 has been deposited at the NCBI database under the $16 \mathrm{~S}$ rRNA gene accession number MH399230 and whole genome accession number QNGD00000000 and BioProject number PRJNA476495. The Sequence Read Archive raw reads are deposited under accession number SRR7647568.

Received: 24 January 2020; Accepted: 28 September 2020

Published online: 12 November 2020

\section{References}

1. Das, P., Mukherjee, S. \& Sen, R. Biosurfactant of marine origin exhibiting heavy metal remediation properties. Bioresour. Technol. 100, 4887-4890 (2009)

2. Nagajyoti, P., Lee, K. \& Sreekanth, T. Heavy metals, occurrence and toxicity for plants: a review. Environ. Chem. Lett. 8, 199-216 (2010).

3. Chibuike, G. \& Obiora, S. Heavy metal polluted soils: effect on plants and bioremediation methods. Appl. Environ. Soil Sci. 1-12, 2014. https://doi.org/10.1155/2014/752708 (2014).

4. Barakat, M. New trends in removing heavy metals from industrial wastewater. Arab. J. Chem. 4, 361-377 (2011).

5. Ayangbenro, A. S. \& Babalola, O. O. A new strategy for heavy metal polluted environments: a review of microbial biosorbents. Int. J. Environ. Res. Public Health 14, 94. https://doi.org/10.3390/ijerph14010094 (2017).

6. Cervantes, C. et al. Interactions of chromium with microorganisms and plants. FEMS Microbiol. Rev. 25, 335-347 (2001).

7. Wuana, R. A. \& Okieimen, F. E. Heavy metals in contaminated soils: a review of sources, chemistry, risks and best available strategies for remediation. ISRN Ecol. 2011, 1-20 (2011).

8. Voica, D. M., Bartha, L., Banciu, H. L. \& Oren, A. Heavy metal resistance in halophilic bacteria and archaea. FEMS Microbiol. Lett. 363, fnw146. https://doi.org/10.1093/femsle/fnw146 (2016).

9. Nahurira, R. et al. In silico genome analysis reveals the metabolic versatility and biotechnology potential of a halotorelant phthalic acid esters degrading Gordonia alkanivorans strain YC-RL2. AMB Express 9, 21. https://doi.org/10.1186/s13568-019-0733-5 (2019).

10. Lin, C. C. \& Lin, H. L. Remediation of soil contaminated with the heavy metal $\left(\mathrm{Cd}^{2+}\right)$. J. Hazard. Mater. 122, 7-15 (2005).

11. Fomina, M. \& Gadd, G. M. Biosorption: current perspectives on concept, definition and application. Bioresour. Technol. 160, 3-14 (2014).

12. Wu, G. et al. A critical review on the bio-removal of hazardous heavy metals from contaminated soils: issues, progress, ecoenvironmental concerns and opportunities. J. Hazard. Mater. 174, 1-8 (2010).

13. Pal, A. \& Paul, A. Microbial extracellular polymeric substances: central elements in heavy metal bioremediation. Indian J. Microbiol. 48, 49-64 (2008).

14. Li, K., Pidatala, V. R., Shaik, R., Datta, R. \& Ramakrishna, W. Integrated metabolomic and proteomic approaches dissect the effect of metal-resistant bacteria on maize biomass and copper uptake. Environ. Sci. Technol. 48, 1184-1193 (2014).

15. Ayangbenro, A. S. \& Babalola, O. O. Metal(loid) bioremediation: strategies employed by microbial polymers. Sustainability 10, 3028. https://doi.org/10.3390/su10093028 (2018).

16. Valls, M. \& De Lorenzo, V. Exploiting the genetic and biochemical capacities of bacteria for the remediation of heavy metal pollution. FEMS Microbiol. Rev. 26, 327-338 (2002).

17. Singh, P. \& Cameotra, S. S. Enhancement of metal bioremediation by use of microbial surfactants. Biochem. Biophys. Res. Commun. 319, 291-297 (2004).

18. Mulligan, C. N. Environmental applications for biosurfactants. Environ. Pollut. 133, 183-198. https://doi.org/10.1016/j.envpo 1.2004.06.009 (2005).

19. Dahrazma, B. \& Mulligan, C. N. Investigation of the removal of heavy metals from sediments using rhamnolipid in a continuous flow configuration. Chemosphere 69, 705-711 (2007).

20. Rizzo, C. et al. Biosurfactant activity, heavy metal tolerance and characterization of Joostella strain A8 from the Mediterranean polychaete Megalomma claparedei (Gravier, 1906). Ecotoxicology 24, 1294-1304 (2015).

21. Cáliz, J. et al. Emerging resistant microbiota from an acidic soil exposed to toxicity of $\mathrm{Cr}, \mathrm{Cd}$ and $\mathrm{Pb}$ is mainly influenced by the bioavailability of these metals. J. Soils Sed. 13, 413-428 (2013). 
22. Hasegawa, M., Kishino, H. \& Yano, T.-A. Dating of the human-ape splitting by a molecular clock of mitochondrial DNA. J. Mol. Evol. 22, 160-174 (1985).

23. Ndeddy Aka, R. J. \& Babalola, O. O. Identification and characterization of $\mathrm{Cr}-, \mathrm{Cd}-$-, and Ni-tolerant bacteria isolated from mine tailings. Bioremediat. J. 21, 1-19 (2017).

24. Xie, Y. et al. Effect of heavy metals pollution on soil microbial diversity and bermudagrass genetic variation. Front. Plant Sci. 7, 775. https://doi.org/10.3389/fpls.2016.00755 (2016).

25. Zampieri, B. D. B., Pinto, A. B., Schultz, L., de Oliveira, M. A. \& de Oliveira, A. J. F. C. Diversity and distribution of heavy metalresistant bacteria in polluted sediments of the Araça Bay, São Sebastião (SP), and the relationship between heavy metals and organic matter concentrations. Microb. Ecol. 72, 582-594 (2016).

26. Çolak, F., Atar, N., Yazıcıoğlu, D. \& Olgun, A. Biosorption of lead from aqueous solutions by Bacillus strains possessing heavymetal resistance. Chem. Eng. J. 173, 422-428 (2011).

27. Oladipo, O. G. et al. Tolerance and growth kinetics of bacteria isolated from gold and gemstone mining sites in response to heavy metal concentrations. J. Environ. Manag. 212, 357-366 (2018).

28. Reith, F., McPhail, D. \& Christy, A. Bacillus cereus, gold and associated elements in soil and other regolith samples from Tomakin Park Gold Mine in southeastern New South Wales, Australia. J. Geochem. Explor. 85, 81-98 (2005).

29. Gnanamani, A. et al. Microbial products (biosurfactant and extracellular chromate reductase) of marine microorganism are the potential agents reduce the oxidative stress induced by toxic heavy metals. Colloids Surf. B. Biointerfaces 79, 334-339 (2010).

30. Shim, J., Babu, A. G., Velmurugan, P., Shea, P. J. \& Oh, B.-T. Pseudomonas fluorescens JH 70-4 promotes $\mathrm{Pb}$ stabilization and early seedling growth of Sudan grass in contaminated mining site soil. Environ. Technol. 35, 2589-2596 (2014).

31. Edwards, S. J. \& Kjellerup, B. V. Applications of biofilms in bioremediation and biotransformation of persistent organic pollutants, pharmaceuticals/personal care products, and heavy metals. Appl. Microbiol. Biotechnol. 97, 9909-9921 (2013).

32. Alisi, C. et al. Bioremediation of diesel oil in a co-contaminated soil by bioaugmentation with a microbial formula tailored with native strains selected for heavy metals resistance. Sci. Tot. Environ. 407, 3024-3032. https://doi.org/10.1016/j.scitotenv.2009.01.011 (2009).

33. Pal, A., Dutta, S., Mukherjee, P. \& Paul, A. Occurrence of heavy metal-resistance in microflora from serpentine soil of Andaman. J. Basic Microbiol. 45, 207-218 (2005).

34. Abou-Shanab, R., Van Berkum, P. \& Angle, J. Heavy metal resistance and genotypic analysis of metal resistance genes in Grampositive and Gram-negative bacteria present in Ni-rich serpentine soil and in the rhizosphere of Alyssum murale. Chemosphere 68, 360-367 (2007).

35. Dell'Amico, E., Mazzocchi, M., Cavalca, L., Allievi, L. \& Andreoni, V. Assessment of bacterial community structure in a long-term copper-polluted ex-vineyard soil. Microbiol. Res. 163, 671-683. https://doi.org/10.1016/j.micres.2006.09.003 (2008).

36. Raja, C. E., Anbazhagan, K. \& Selvam, G. S. Isolation and characterization of a metal-resistant Pseudomonas aeruginosa strain. World J. Microbiol. Biotechnol. 22, 577-585 (2006).

37. Achal, V., Pan, X., Fu, Q. \& Zhang, D. Biomineralization based remediation of As (III) contaminated soil by Sporosarcina ginsengisoli. J. Hazard. Mater. 201, 178-184 (2012).

38. Bloem, J. \& Breure, A. M. In Trace Metals and Other Contaminants in the Environment Vol. 6 (eds Markert, B. A. et al.) 259-282 (Elsevier, Amsterdam, 2003).

39. Giller, K. E., Witter, E. \& McGrath, S. P. Heavy metals and soil microbes. Soil Biol. Biochem. 41, 2031-2037. https://doi.org/10.1016/j. soilbio.2009.04.026 (2009).

40. Ianeva, O. D. Mechanisms of bacteria resistance to heavy metals. Mikrobiol. Z. 71, 54-65 (2009).

41. Govarthanan, M. et al. Significance of autochthonous Bacillus sp. KK1 on biomineralization of lead in mine tailings. Chemosphere 90, 2267-2272. https://doi.org/10.1016/j.chemosphere.2012.10.038 (2013).

42. Shin, M.-N. et al. Characterization of lead resistant endophytic Bacillus sp. MN3-4 and its potential for promoting lead accumulation in metal hyperaccumulator Alnus firma. J. Hazard. Mater. 199, 314-320 (2012).

43. Nies, D. H., Nies, A., Chu, L. \& Silver, S. Expression and nucleotide sequence of a plasmid-determined divalent cation efflux system from Alcaligenes eutrophus. Proc. Natl. Acad. Sci. 86, 7351-7355 (1989).

44. Wu, W. et al. Genome sequencing reveals mechanisms for heavy metal resistance and polycyclic aromatic hydrocarbon degradation in Delftia lacustris strain LZ-C. Ecotoxicology 25, 234-247 (2016).

45. Naik, M. M. \& Dubey, S. K. Lead resistant bacteria: lead resistance mechanisms, their applications in lead bioremediation and biomonitoring. Ecotoxicol. Environ. Saf. 98, 1-7 (2013).

46. Kumar, M., Kumar, M., Pandey, A. \& Thakur, I. S. Genomic analysis of carbon dioxide sequestering bacterium for exopolysaccharides production. Sci. Rep. 9, 4270. https://doi.org/10.1038/s41598-019-41052-0 (2019).

47. Schmid, J., Sieber, V. \& Rehm, B. Bacterial exopolysaccharides: biosynthesis pathways and engineering strategies. Front. Microbiol. 6, 496. https://doi.org/10.3389/fmicb.2015.00496 (2015).

48. Bicca, F. C., Fleck, L. C. \& Ayub, M. A. Z. Production of biosurfactant by hydrocarbon degrading Rhodococcus ruber and Rhodococcus erythropolis. Rev. Microbiol. 30, 231-236 (1999).

49. Kumar, A. P. et al. Evaluation of orange peel for biosurfactant production by Bacillus licheniformis and their ability to degrade naphthalene and crude oil. 3 Biotech 6, 1-10 (2016).

50. Carrillo, P., Mardaraz, C., Pitta-Alvarez, S. \& Giulietti, A. Isolation and selection of biosurfactant-producing bacteria. World J. Microbiol. Biotechnol. 12, 82-84 (1996).

51. Sriram, M. I. et al. Biofilm inhibition and antimicrobial action of lipopeptide biosurfactant produced by heavy metal tolerant strain Bacillus cereus NK1. Colloids Surf. B. Biointerfaces 85, 174-181 (2011).

52. Tuleva, B., Christova, N., Jordanov, B., Nikolova-Damyanova, B. \& Petrov, P. Naphthalene degradation and biosurfactant activity by Bacillus cereus 28BN. Z. Naturforsch. C 60, 577-582 (2005).

53. Bento, F. M., de Oliveira Camargo, F. A., Okeke, B. C. \& Frankenberger, W. T. Jr. Diversity of biosurfactant producing microorganisms isolated from soils contaminated with diesel oil. Microbiol. Res. 160, 249-255 (2005).

54. Barakat, K. M., Hassan, S. W. \& Darwesh, O. M. Biosurfactant production by haloalkaliphilic Bacillus strains isolated from Red Sea, Egypt. Egypt. J. Aquat. Res. 43, 205-211 (2017).

55. Heryani, H. \& Putra, M. D. Kinetic study and modeling of biosurfactant production using Bacillus sp. Electron. J. Biotechnol. 27, 49-54 (2017).

56. Satpute, S., Bhawsar, B., Dhakephalkar, P. \& Chopade, B. Assessment of different screening methods for selecting biosurfactant producing marine bacteria. Indian J. Mar. Sci. 37, 243-250 (2008).

57. Pereira, J. F. et al. Optimization and characterization of biosurfactant production by Bacillus subtilis isolates towards microbial enhanced oil recovery applications. Fuel 111, 259-268 (2013).

58. Khopade, A. et al. Production and stability studies of the biosurfactant isolated from marine Nocardiopsis sp. B4. Desalination 285, 198-204 (2012).

59. Zou, C. et al. Characterization and optimization of biosurfactants produced by Acinetobacter baylyi ZJ2 isolated from crude oilcontaminated soil sample toward microbial enhanced oil recovery applications. Biochem. Eng. J. 90, 49-58. https://doi.org/10.1016/j. bej.2014.05.007 (2014).

60. Rivardo, F., Turner, R., Allegrone, G., Ceri, H. \& Martinotti, M. Anti-adhesion activity of two biosurfactants produced by Bacillus spp. prevents biofilm formation of human bacterial pathogens. Appl. Microbiol. Biotechnol. 83, 541-553 (2009). 
61. Jasim, B., Sreelakshmi, K., Mathew, J. \& Radhakrishnan, E. Surfactin, iturin, and fengycin biosynthesis by endophytic Bacillus sp. from Bacopa monnieri. Microb. Ecol. 72, 106-119 (2016).

62. Cho, S.-J., Lee, S. K., Cha, B. J., Kim, Y. H. \& Shin, K.-S. Detection and characterization of the Gloeosporium gloeosporioides growth inhibitory compound iturin A from Bacillus subtilis strain KS03. FEMS Microbiol. Lett. 223, 47-51 (2003).

63. Chen, H., Chen, Z., Zhang, Y. \& Zhu, W. Identification of antifungal peptides from Bacillus subtilis Bs-918. Anal. Lett. 47, 2891-2899 (2014).

64. Akpa, E. et al. Influence of culture conditions on lipopeptide production by Bacillus subtilis. Appl. Biochem. Biotechnol. 91, 551-561 (2001).

65. Singh, A. K. \& Cameotra, S. S. Efficiency of lipopeptide biosurfactants in removal of petroleum hydrocarbons and heavy metals from contaminated soil. Environ. Sci. Pollut. Res. 20, 7367-7376 (2013).

66. Ochoa-Loza, F. J., Noordman, W. H., Jannsen, D. B., Brusseau, M. L. \& Maier, R. M. Effect of clays, metal oxides, and organic matter on rhamnolipid biosurfactant sorption by soil. Chemosphere 66, 1634-1642 (2007).

67. da Rocha Junior, R. B. et al. Application of a low-cost biosurfactant in heavy metal remediation processes. Biodegradation 30, 215-233. https://doi.org/10.1007/s10532-018-9833-1 (2019).

68. Mulligan, C. N., Yong, R. N. \& Gibbs, B. F. Heavy metal removal from sediments by biosurfactants. J. Hazard. Mater. 85, 111-125 (2001).

69. Rajkumar, M. \& Freitas, H. Influence of metal resistant-plant growth-promoting bacteria on the growth of Ricinus communis in soil contaminated with heavy metals. Chemosphere 71, 834-842 (2008).

70. Kumar, S., Stecher, G., Li, M., Knyaz, C. \& Tamura, K. MEGA X: molecular evolutionary genetics analysis across computing platforms. Mol. Biol. Evol. 35, 1547-1549 (2018).

71. Babalola, O. O., Aremu, B. R. \& Ayangbenro, A. S. Draft genome sequence of heavy metal-resistant Bacillus cereus NWUAB01. Microbiol. Resour. Announc. 8, e01706-01718. https://doi.org/10.1128/mra.01706-18 (2019).

72. 72Arkin, A. P. et al. The DOE systems biology knowledgebase (KBase). bioRxiv, 096354 (2016).

73. Bolger, A. M., Lohse, M. \& Usadel, B. Trimmomatic: a flexible trimmer for Illumina sequence data. Bioinformatics 30, 2114-2120 (2014).

74. Nurk, S. et al. Assembling single-cell genomes and mini-metagenomes from chimeric MDA products. J. Comput. Biol. 20, 714-737 (2013).

75. Haft, D. H. et al. RefSeq: an update on prokaryotic genome annotation and curation. Nucleic Acids Res. 46, D851-D860 (2017).

76. Aziz, R. K. et al. The RAST server: rapid annotations using subsystems technology. BMC Genom. 9, 75 (2008).

77. Blin, K. et al. antiSMASH 5.0: updates to the secondary metabolite genome mining pipeline. Nucleic Acids Res. 47, W81-W87 (2019).

78. Wattam, A. R. et al. Improvements to PATRIC, the all-bacterial bioinformatics database and analysis resource center. Nucleic Acids Res. 45, D535-D542 (2016).

79. Gond, S. K., Bergen, M. S., Torres, M. S. \& White, J. F. Jr. Endophytic Bacillus spp. produce antifungal lipopeptides and induce host defence gene expression in maize. Microbiol. Res. 172, 79-87 (2015).

\section{Acknowledgements}

ASA will like to thank the North-West University for postdoctoral fellowship granted to him.

\section{Author contributions}

ASA and OOB conceived and designed the project. ASA isolated, characterized, and analyzed the genome of the strain. ASA wrote the manuscript, and OOB interpreted the data analysis, critically revised various drafts, ensure quality assurance and supervised the study. All authors read and approved the final manuscript.

\section{Funding}

We acknowledge the support of The World Academy of Science (TWAS) and the National Research Foundation (NRF) of South Africa for stipend to ASA (UID99779) and grant (UID123634) that supports work in OOB lab.

\section{Competing interests}

The authors declare no competing interests.

\section{Additional information}

Supplementary information is available for this paper at https://doi.org/10.1038/s41598-020-75170-x.

Correspondence and requests for materials should be addressed to O.O.B.

Reprints and permissions information is available at www.nature.com/reprints.

Publisher's note Springer Nature remains neutral with regard to jurisdictional claims in published maps and institutional affiliations.

Open Access This article is licensed under a Creative Commons Attribution 4.0 International License, which permits use, sharing, adaptation, distribution and reproduction in any medium or format, as long as you give appropriate credit to the original author(s) and the source, provide a link to the Creative Commons licence, and indicate if changes were made. The images or other third party material in this article are included in the article's Creative Commons licence, unless indicated otherwise in a credit line to the material. If material is not included in the article's Creative Commons licence and your intended use is not permitted by statutory regulation or exceeds the permitted use, you will need to obtain permission directly from the copyright holder. To view a copy of this licence, visit http://creativecommons.org/licenses/by/4.0/.

(C) The Author(s) 2020 